\title{
Urban Agency in the Borderlands: Turkmen Rulers and Administrative Elites in 13th-century Kastamonu
}

\author{
Bruno De Nicola*
}

After the Battle of Manzikert (1071), in which the armies of the Great Seljuqs defeated the Byzantine Empire, different waves of Turkmen people settled across Anatolia. By the 12th century, many of these groups had organised under the command of local warlords and established military control over different areas of Asia Minor under the tutelage of the Seljuqs of Rum. However, the mechanisms by which the new rulers articulated their control, especially over the urban settlements located in the regions they conquered, are poorly understood. This is even more dramatic in the case of northwestern Anatolia, a region that, during the 13th century, was a borderland between an expanding Turco-Islamic world and a defensive Christian Byzantium. The lack of narrative sources dealing with this particular part of Asia Minor has aggravated this lacuna, often excluding the city of Kastamonu from the studies of urban settlement in 13th-century Anatolia. This article attempts to change this situation by looking at surviving architectural evidence and non-narrative-literary sources that offer a particular view of the agents and agencies at work in the interaction between Turkmen rulers and urban elites in 13th-century Kastamonu.

Keywords: Kastamonu, Chobanids, medieval Anatolia, administrative literature, urban agency, Husām al-Dìn Khǜ ì, Rum Seljuqs

* Correspondence details: Dr. Bruno De Nicola, Austrian Academy of Sciences (OEAW) and Goldsmiths, University of London. OEAW, Hollandstrasse 11-13, 1020 Vienna, Austria; bruno.denicola@oeaw.ac.at.

This article is part of the themed section Urban Agencies: Reframing Anatolian and Caucasian Cities (13th-14th Centuries), guest editors: Bruno De Nicola and Matthew Kinloch. To read all related articles, please access: dx.doi. org/10.1553/medievalworlds_no14_2021. 


\begin{abstract}
"The circumstances in which the principality of Kastamonu was established are difficult to determine since, on account of its remoteness from the political centres, it attracted little attention from the chroniclers. ${ }^{1}$
\end{abstract}

\title{
Introduction
}

The region of Kastamonu, which by and large corresponds geographically with the former Byzantine region of Paphlagonia, occupies a marginal position in the major Muslim historical narratives produced in Anatolia during the 13th century. ${ }^{2}$ Byzantine sources, such as Pachymeres or Gregoras, are not very helpful either. ${ }^{3}$ They offer confusing accounts, often contradicting themselves, with imprecise chronologies that describe actors that are difficult to identify with historical personalities. ${ }^{4}$ However, one certainty about the history of the region in this period is the early presence of Turkmen groups in the area, documented from at least the late 11th century as a factor of conflict and confrontation. ${ }^{5}$ The majority of the accounts we have for this period vary from the catastrophist narratives of Greek sources depicting a territory flooded with Turkmen warriors to references of doubtful historical origin scattered in later Muslim sources to heroic ghazi warriors. ${ }^{6}$ After a short-lived reconquest of the region from the Danishmandids by John Comnenus in the 1130s, Turkmen groups continued to migrate and settle in the area until, by the mid-12th century, Byzantine forces had retreated completely and Turkmen groups seemed to have established military control over the Kastamonu countryside. During the reign of the Seljuq Sultan Rukn al-Dīn Sulaymān Shāh II (r. 1196-1204), the region of Kastamonu became closely bound to the Seljuqs of Rum, despite maintaining an important degree of political autonomy. By the 13th century, Ibn Sa'id al-Maghribì, an Andalusian traveller who visited Anatolia, mentions that this region was a "stronghold of the Turkomans«.7

The main urban settlement in northwestern Anatolia during the 13th century was the city of Kastamonu, with the smaller towns of Taşköprü (Pompeiopolis) and Safranbolu (Zalifre) to the east and west respectively. ${ }^{8}$ In previous works we have centred our attention on the political position that the Chobanids of Kastamonu occupied in relation to the Seljuq and Mongol polities in 13th century Anatolia. ${ }^{9}$ The present article, however, aims

1 Cahen, Pre-Ottoman Turkey, 310.

2 Major narrative sources in Persian for the history of medieval Anatolia are Ibn Bībì, El-Evamirü'l-'Alâ'iyye, ed. Sadık Erzi; Ibn Bībī, al-Avāmir al-'alā'ìyah, ed. Muttahịīin; Aqsarāìi, Musāmarat al-akhbār, ed. Turan; Anonymous, Tärìkh-i Āl-i Saljūq dar Ānāțūlì, ed. Jalālī.

3 Pachymeres, Relations historiques, ed. and trans. Failler; Gregoras, Byzantina Historia, ed. Schopen; Akropolites, George Akropolites, trans. Macrides.

4 For an overview of Byzantine sources in this period, see Neville, Guide to Byzantine Historical Writing, 237-242 and Korobeinikov, Byzantium and the Turks, 7-39.

5 Cahen, Pre-Ottoman Turkey, 73; Vryonis, Decline of Medieval Hellenism, 111-112.

6 See, for example, the legend of amir Karatekin, the renowned Turkic conqueror of the Greek province of Paphlagonia (i.e. Kastamonu), in Sevim and Yücel, Türkiye Tarihi, 181; Yınanç, Anadolu Selçukiler tarihine, 96; Döğüş, Osmanli Fütuhatina Candarli Sahasindan Gelen Yardimlar, 415-416.

7 Quoted in Encyclopaedia of Islam, Second Edition, s.v. "Ḳasțamūnī«, accessed on 3 March 2021: dx.doi. org/10.1163/1573-3912_islam_SIM_4008.

8 The town of Safranbolu has also been connected to the former Byzantine town of Dadybra, which, according to some sources, was taken over by the local Turkmen ruler of Ankara in the late 12th century. See Choniates, $O$ city of Byzantium, 260.

9 De Nicola, In the outskirts of the Ilkhanate. 
to explore alternative literary and archaeological evidence from the region to unveil different agents and agencies that participated in the establishment and consolidation of a new Turkmen dynasty (the Chobanids) in Kastamonu. We argue that the relationship between Turkmen rulers and urban settlements in the region was not homogenous and rather followed a number of stages in which both rulers and subjects actively contributed to the political, religious and cultural symbiosis that characterised Kastamonu during the 13th century.

\section{Chobanid Occupation of Kastamonu: An Overview of Architectural Evidence}

The political history of 13th-century Kastamonu is marked by the Chobanid dynasty (r. c. 1211c. 1309). The Chobanids belonged to the Turkmen groups that entered Anatolia in successive waves after the Battle of Manzikert (1071). At the turn of the 13th century, an elite military group of Turkmen commanded by Ḥusām al-Dīn Chūpān (d. c. 1240) established themselves in northwestern Anatolia. ${ }^{10}$ Although the Chobanids occasionally extended their influence into areas such as Tokat, Ankara or Sinop, their military and political authority was mainly circumscribed by the region of Kastamonu. Although in recent years we have advanced in forming a more nuanced idea about the political development of Chobanid rule in the area, we still know very little about the relationship between these Turkmen military elites and the territory they controlled. The area of Kastamonu in the 13th century consisted of hilly terrain dominated by forests. Although it was not among the more fertile areas of Anatolia, it nonetheless sustained some agricultural activity. Its location at the crossroads of trade routes connecting the Black Sea with the Mediterranean on the one hand and Central Anatolia with Constantinople on the other resulted in moderate but lucrative commercial activities that produced important economic benefits to the Turkmen rulers and favoured the consolidation of urban centres in the region.

The first historical reference to the Chobanids does not appear until 1211, when Husām al-Dīn Chūpān intervened militarily in support of the Seljuq prince Kayqubād at the Battle of Ankara against his brother Kaykā'ūs I (r. 1211-1220). The Chobanids lost this battle, but their early support for the defeated prince would become a political asset a few years later when Kayqubād I (r. 1220-1237) replaced his brother as Sultan of Rum. It is in the early 1220s when a new reference to the military capabilities of the Chobanid ruler appears in local chronicles. Ibn Bỉbi dedicates part of his historical narrative to highlighting the important role played by Ḥusām al-Dīn (now referred to as amìr) in the reconquest of the city of Sudak in Crimea in $1223 .{ }^{11}$ The Chobanid ruler is praised for successfully commanding the only maritime expedition of the Seljuqs of Rum, after which he returned to Kastamonu as a victorious and loyal commander of the Seljuq sultan. ${ }^{12}$ However, between his return and the 1280 os, we lack any concrete documentary evidence of how this local Turkmen dynasty controlled the region under their command.

On the political history of the Chobanids of Kastamonu, see Yücel, Anadolu Beylikleri Hakkında Araştırmalar, vol. 1, 33-51; De Nicola, Chobanids of Kastamonu.

11 Ibn Bībì, al-Avāmir al- alä iyya, ed. Muttahidīn, 281-284.

12 Peacock, Saljūq Campaign, 133-149. 
Although modern historiography has generally considered that the Chobanids were »in charge" of the region throughout this period, they apparently had little, if any, control over the city of Kastamonu itself. Claude Cahen has suggested, for example, that wall that can be said with certainty is that Ḥusām al-Dīn Chūpān governed for a long time, and that Kastamonu was a city belonging to the Sultan. ${ }^{13}{ }^{13}$ In fact, it seems that the city of Kastamonu, like the region, remained somehow under the nominal control of the Seljuqs of Rum in the form of an $i q t \bar{a}$ ' territory. This meant that the Seljuqs of Rum could transfer fiscal and administrative control over Kastamonu to officials or local rulers and it was not considered part of the sultan's personal property (khäsș). ${ }^{14}$ This special political and fiscal status of the city might explain why, during the central decades of the 13th century, Kastamonu passed into the hands of various administrators belonging to either the Seljuq royal family or the Mongol administration..$^{15}$ Hence, while the city of Kastamonu remained under the administrative control of Seljuq and Mongol officials, the Chobanids were important military and political actors in the area, possibly acting as military protectors of the region and obtaining tribute from the residents of the town.

The architectural footprint of the Chobanids in Kastamonu is certainly modest and hardly spectacular when compared to other regions of Anatolia. This explains why the majority of archaeological surveys published recently on medieval Anatolia often do not include references to the architectural legacy of Chobanid Kastamonu. However, the few remaining structures still standing in the region offer some interesting insights into the relationship between these Turkmen rulers and the Kastamonu countryside. Because these buildings have been reconstructed in modern times, they offer little information regarding original architectural style or construction techniques. However, the mapping of these structures dating to the first half of the 13th century offers a unique perspective on the settlement of Turkmen populations in northwestern Anatolia during a period when we lack any documentary evidence.

The surviving structures from the early period of Chobanid presence in the region all have a religious component. The majority of them are small mausoleums (türbeler) of early Sufi shaykhs or Muslim ghazi-martyrs that allegedly died in battle against Byzantine forces during the Turkmen conquest of northwestern Anatolia in the 12th century. The earlier example of this type of construction in the region is the tomb of the Khurasani martyr Şeyh Ahmet, who allegedly came to Anatolia before 1206 and fought against the Byzantines in the area. The structure, highly restored and rebuilt in subsequent periods, is located outside of the city, in the present district of Gölköy, around $12 \mathrm{~km}$ north of the city centre. ${ }^{16}$ Similar mausoleums dating from before the 1270 s appear to have spread across the territory around, but

Mongol officials might have received rights of usufruct over the region as a way to pay for the sultanate's debts following the Seljuq defeat by the Mongols at the Battle of Kösedağ in 1243; see Korobeinikov, Revolt of Kastamonu, 90-91. On the battle, see Ylldı, Mongol Rule, 182-187.

16 Yaman, Kastamonu tarihi, 85. 
not inside, urban settlements. Shrines are especially numerous along the road connecting the cities of Kastamonu and Sinop. The latter became not only an area of Chobanid influence during this period but also channelled modest but regionally important commercial activity that connected the Black Sea with Inner Anatolia and the Mediterranean. ${ }^{17}$ These individual tombs and mausoleums played an important role as centres of pilgrimage, reunion and worship for travellers and Turkmen populations that protected the territory.

The surviving architecture in the region of Kastamonu gives evidence that it was in the countryside where Islam began to take root in the region. The first documented mosque to be built in the area belongs to this early period of Turkmen domination of the region. A few kilometres south of the city of Kastamonu, in the Akçasu neighbourhood of the modern town of Kuzyaka, is the Akçasu Mosque, apparently founded during the first half of the 13th century.$^{18}$ Little survives today of the original structure of the building; renovations done during the 2oth century appear to have changed the shape and the appearance of the building. However, its early date is important in establishing the progress of Islamisation in the area. This small structure, constructed on the outskirts of Kastamonu, likely had little impact on the city itself or the religious life of its inhabitants. It is possible that by the 1250s, when the Akçasu Mosque was built, the majority of the population of the city of Kastamonu was still Christian. However, as an early Islamic building in the region, it might have served as a place of worship for the recently Islamised Turkmen who had been dwelling in rural northwestern Anatolia since the late 12th century.

The architectural landscape of the region of Kastamonu changes from the 1270s onwards, when the first Islamic buildings began to be constructed inside the city walls. Perhaps the best example of this transformation is the construction of the Atabey Gazi (Ghāzī) Mosque, built in the same rectangular shape as the rural Akçasu Mosque but on a larger scale. ${ }^{19}$ This new building, however, would be located inside the city, only a few metres downhill from the surviving Byzantine castle that oversees the city of Kastamonu. The mosque takes the name of the legendary figure of Atabey Gazi, a hero-like figure who allegedly fought in the region against the Byzantines in the 12th century. Traditions around the foundation of the mosque mention that the original Christian church that stood on the site was converted into a mosque on a Friday by the Turkmen general who took the city from the Byzantines. This commander allegedly expelled the Christian clerics while they were delivering a sermon and from that day onwards the building became the congregational mosque where Friday prayers were conducted by Muslims. ${ }^{20}$ The story may well be a fabrication, since the only thing we know for certain about the foundation of the building is that it was consecrated in 1273, according to an inscription which has survived on the wall of the mosque. No archaeological

17 Cahen, Pre-Ottoman Turkey, 320; Peacock, Black Sea trade, 69-70. For an overview of trade in the Black Sea, see Ciociltan, Mongols and the Black Sea.

18 Kara, Her yönüyle, 197.

19 For a comprehensive overview of the building, see Çal and Çal, Kastamonu Atabey Gazi Camisi.

20 Acar, Çobanoğullan Beyliği, 43; Çiftçi, Kastamonu Camileri-Türbeleri ve Diğer Eserler, 91-93. 
evidence of a pre-existing church in the place has been found so far, but the popularity of the story may indicate how the Muslim occupation of the city was presented to Muslim and non-Muslim inhabitants alike after the construction of the mosque. ${ }^{21}$ This monument, together with similar monuments found in other parts of northwestern Anatolia, may reveal very early attempts to create a memory of a Muslim past during the 13th century for the region of Paphlagonia possibly remained largely inhabited by Christian populations. ${ }^{22}$

Mirroring what occurred in the countryside decades earlier, secular and religious türbeler (mausoleums) also began to appear side by side with mosques inside the city walls in the second half of the 13th century. Mausoleums containing the bodies of Turkic military commanders were erected in different parts of the city. One dedicated to Aşikli Sultan, supposedly a Seljuq commander who became a martyr after falling during the conquest of the Kastamonu Castle from the Byzantines in the early 12th century, is still standing in the northern part of the medieval city. ${ }^{23}$ Another mausoleum, allegedly holding the mortal remains of Husām al-Dīn Chūpān, founder of the dynasty, was erected next to the Atabey Gazi Mosque. ${ }^{24}$ In addition, a number of Sufi shrines were constructed in the city during this period. Under the later Ottoman Nașr Allāh Mosque in the centre of the city of Kastamonu there is a grave that has been dated to $671 \mathrm{AH}$ [1272 CE]. Apparently, in the 13th century, the building functioned as a hospital where Shaykh Abd al-Fattāh-i Walī (Abdülfettah-ı Veli, d. 1272) used to reside and perform healings. ${ }^{25}$ It became an important centre of pilgrimage in the 13th century, reinforced by the claim that the shaykh was a son of 'Abd al-Qādir al-Jīannī (d. 1166), the founder of the Qãdiriyya Sufi order. ${ }^{26}$ It seems that the foundation of a mosque and the mushrooming of these türbeler inside the city after 1270 had a dual function. On the one hand, they functioned as places of pilgrimage to satisfy the religious needs of a growing Muslim population inside the city walls. On the other, they acted as visual representations to the inhabitants of a growing Turkmen presence in the city.

This Turkmen patronage of architecture in the urban landscape of 13th-century Kastamonu was not limited to the capital city. In the city of Taşköprü, located some 50 kilometres northeast of Kastamonu, a public fountain and a public bath were also built during the 1270 s. ${ }^{27}$ Unfortunately, the fountain was destroyed during a fire in 1927 but the bathhouse (hammām) and a bazaar are mentioned by the Maghrebi traveller Ibn Baț̣ūta as being endowments by the Chobanid Muẓaffar al-Dīn, grandson of Ḥusām al-Dīn Chūpān, to the congregational mosque in the town. ${ }^{28}$ In addition, the Chobanid ruler also founded a Sufi

21 Acar, Çobanoğulları Beyliği, 41-42.

22 A parallel case could be the castle of the town of Çankırı, located only one hundred kilometres south of Kastamonu, where there is a türbe (tomb) allegedly containing the remains of amir Karatekin, a semi-legendary Muslim hero who conquered the city in the second half of the 12th century; aee Kuru, Çankırı Fatihi Emir Karatekin'in Türbesi, 63-84.

23 Kara, Her yönüyle, 202; Çiftçi, Kastamonu camileri, türbeleri ve diğer tarihi eserler, 173.

24 Acar, Çobanoğulları Beyliği, 46.

25 Kara, Her yönüyle, 199

26 Encyclopaedia Iranica 1/2, s.v. 'Abd-al-Qāder Jilānī; an updated version is available online at www.iranicaonline. org/articles/abd-al-qader-jilani.

27 Yakupoğlu, Kastamonu-Taşköprü, 46.

28 Ibn Battuta, Travels of Ibn Battuta, 2, ed. Gibb, 464, fn. 186. 
zäwiyya (located in the nearby village of Tokaş) and a madrasa was built in the town of Taşköprü to provide religious education to its residents. ${ }^{29}$ According to some surviving later endowments ( $a w q \bar{a})$ ), both the madrasa and the mosque remained important centres of religious life during the subsequent Jandarid and Ottoman dynasties that ruled Taşköprü after the Chobanids. ${ }^{30}$ Evidence suggests that Muzaffar al-Dīn Chūpān acted as a governor in the name of his father before assuming control of the emirate in $1280 .{ }^{31}$ Thus, patronage of urban architecture was not isolated to the capital. Instead, it appears that a coordinated building strategy was carried out by the Chobanids in order to demonstrate their direct involvement in the urban landscape under their control from the 1270 s onward..$^{32}$

\section{Consolidating Turkmen Rule: Chobanid Literary Patronage}

The architectural patronage that began to emerge in the cities of the region of Kastamonu in the 1270s was led by Alp Yürek (d. 1280), son of Ḥusām al-Dīn Chūpān. Alp Yürek's son, Muzaffar al-Din, who resided in the city of Taşköprü, moved to the capital to become the new ruler of Kastamonu after the death of his father. Muzaffar al-Din's ascension to the throne would be a crucial moment in the history of the region. In an unprecedented move among the Chobanids, he would extend his father's policy of patronage from architecture into literature. However, the realisation that literary patronage could play a role in legitimising Turkmen rule in the region did not come as an epiphany to the young ruler but rather seems to have originated on a particular trip that Muzaffar al-Din had to make to the Ilkhanid capital of Tabriz.

In the complex political scenario of 13th-century Anatolia, Muzaffar al-Dinn's ascension to the throne needed the approval of the supraregional powers in the area, not only to renew his ancestor's military rights over the region but also to legitimise the closer political, economic and religious control of the Chobanids in the area. The new ruler quickly got involved in the ever-unstable political arena of the Seljuqs of Rum by supporting the claims of Prince Mas ùd (Mesud) to the sultanate against the claims of his brother Rukn al-Dinn. Muzaffar al-Dīn captured Rukn al-Dīn on his arrival in Anatolia from the Crimea and imprisoned him in the castle of Kastamonu before handing him over to his brother Mas'ùd. This move by Muzaffar al-Din played out well for him, and he became the main ally of the new pretender to the Seljuq throne. ${ }^{33}$

With Rukn al-Dīn removed from the political scene, both Mas'ùd and Muzaffar al-Dīn needed the support of the major political and military power of the region, the Mongol Ilkhans of Iran. In search of Mongol approval for their political alliance, both Mas ùd and Muzaffar al-Din made a journey to the Mongol capital of Tabriz shortly before 1282 with the idea of requesting the sultanate for Mas ùd and the emirate for Muzaffar al-Din from the Ilkhan Abaqa (r. 1265-1282). Unfortunately, by the time of their arrival in the Mongol capital, the Ilkhan had died. The delicate political balance of the Ilkhanid court during the reign

33 Ibn Bībī, al-Avāmir al-'alā’̀̄yah, ed. Muttahidīn, 634-635. 
of his successor Tegüder Ahmad (r. 1282-1284) forced the two Anatolian rulers to remain in Tabriz for longer than originally planned in order to secure the political endorsement they needed from the Mongols. After a number of intrigues and political disputes, Mas'ùd was confirmed as Sultan of Rum and Muzaffar al-Dīn as Sipahsālār of Kastamonu in 1284. ${ }^{34}$ However, the almost three years that Muzaffar al-Din apparently spent in the Ilkhanid capital seem to have had a special impact on the mind of Muzaffar al-Dinn. In the late 13th century, Tabriz was not only the capital of the Ilkhanate, but also one of the cultural, economic and political centres of the Islamic world..$^{35}$ In comparison, Kastamonu, with its rudimentary Islamic architecture financed by the Chobanids, seemed like nothing but a rural town on the outskirts of the world, described by a visitor as a rather desolate place (mawtin-i nuzūl). ${ }^{36}$ Therefore, in the eyes of a Turkmen warlord such as Muzaffar al-Dīn, Tabriz would have been a sharp contrast to his hometown.

It appears that Muzaffar al-Din was especially impressed with the cultural life of the Mongol capital, which at the time had some of the most prominent scholars, men of letters and artists in the Islamic world. Consequently, on his return to Kastamonu in 1284, Muzaffar al-Din was now a political ally of both the Mongols and the Seljuq sultan, which allowed him to develop an ambitious policy of literary patronage. Influenced by his experience in the Ilkhanid capital, he actively tried to make Kastamonu into a centre of literary activity that mirrored, to a much lesser extent, Mongol Tabriz and Seljuq Konya.

In terms of prestige, the most remarkable achievement of Muzaffar al-Din was to obtain the dedication of Ikhtiyārāt-i Muzaffarī, an astronomical treatise in Persian by the famous scholar Quṭb al-Dīn Shìrāzì (d. 1311). ${ }^{37}$ The circumstances under which this book by such a famous author was named after a rather marginal warlord of a distant border zone are not clear. Niazi has studied this matter and has suggested two possible scenarios in which both the Turkmen ruler and the scholar could have met. One possibility is that they met in Tabriz when Quṭb al-Dīn Shīrāzì paid a visit to the court of the Ilkhans during Muzaffar al-Dīn's stay in the Mongol capital. The other possibility is that Muzaffar al-Din might have made contact with the Persian scholar and requested the work while passing through Sivas or Malatya, two cities where Quṭb al-Dīn Shìrāzì lived in the second half of the 13th century. ${ }^{38}$ Because the Ikhtiyārät-i Muzaffari appears to have been composed in 1282, a date when we know that the Chobanid ruler was in Tabriz, the first hypothesis seems more plausible. The proximity between the date of composition of the work and the arrival of Muzaffar al-Dinn in Tabriz also suggests that the text might not have been commissioned by Muzaffar al-Din but rather dedicated to him after it had already been written. In other words, it seems that an opportunity was recognised by both Quṭb al-Dīn Shīrāzī, who certainly received a financial reward for his work, and Muzaffar al-Dīn, whose name became attached to one of the most prestigious scholars of his time.

37 This work, written in Persian, is a rescission of two more extensive works by Shīrāzī composed only a few years previously in Arabic; see Niazi, Quțb al-Dīn Shïrāzī, 87-95. For an early manuscript of this work, see Istanbul, Süleymaniye Library, Fatih 5302, fol. 2r.

38 Niazi, Quțb al-Dìn Shìrāzī, 80-82. 
The dedication of Shīrāzì's book was not an isolated act by Muzaffar al-Dīn. After returning to Kastamonu in 1284, he developed a policy of literary patronage that would continue until the end of the dynasty. That same year, for example, a book entitled Fustạt al-'adāla fì qawä ì al-saltana, composed in $683 \mathrm{AH}$ (1284-5 CE) was dedicated to Muzaffar al-Dīn. ${ }^{39} \mathrm{Be}$ cause only one incomplete manuscript survives of this work, its author and place of composition are disputed.$^{40}$ However, it appears that the author may have composed the work in the city of Aksaray before offering it to Muzaffar al-Dīn. ${ }^{41}$ Whether the author visited Kastamonu to offer the work or the Chobanid ruler met the author during his trip to Tabriz is difficult to ascertain. The Fusțât al-'adāla is a very different text from that composed by Quṭb al-Dīn Shīrāzì. It includes a rewriting of the famous administrative treatise Siyar al-Mulūk, complemented by a particular concern for advising rulers on how to reinforce Islamic values, law and Islamic orthodoxy against the spread of heresies. ${ }^{42}$ It contains the earliest descriptions of Antinomian Sufis as heretical groups (qalandars), followed by a long didactical exposition of the commonalities between Shafīi and Hanafi schools of law.

The most prolific of the authors receiving patronage from the Chobanid court was Husām al-Dīn Khü'î, who not only lived and worked in the Chobanid territories but also played a crucial role in developing a theoretical framework and practical tools for the Turkmen administration of Kastamonu, as will be discussed below. No works by Ḥusām al-Dīn composed prior to the 1280 s have survived; he might have been attracted to northwestern Anatolia by the policies of literary patronage initiated by Muzaffar al-Dīn Chūpān after his return from the Ilkhanid court in 1284. The works composed by Husām al-Dīn differ from those mentioned above in scope and contents. Unlike the astronomical treatise of Quṭb al-Dīn Shìrāzì and the religious component of the Fusțāt al-'adāla, Ḥusām al-Dīn Khūî̀'s works show a particular interest in administrative literature and a concern for the correct use of language in the administration of the realm. Seven works are attributed to him, although he can really only be credited with authoring six of them. ${ }^{43}$ Of these six, two were dedicated to Chobanid rulers, dealing mostly with treatises on insh $\vec{a}^{\prime}$ literature and vocabularies. ${ }^{44}$ The first, the

39 Paris, Bibliothèque nationale de France, Turc 1120.

40 The author is possibly Muhammad al-Khātịb, according to the description given by Çelebi, (Keş̧-el-Zunun, ed. Yaltkaya and Bilge, col. 1259) of another alleged copy of the same work, now lost.

41 Çelebi, Keşf-el-Zunun, ed. Yaltkaya and Bilge, col. 1259.

42 De Nicola, Fusțāt al-'adāla, 49-72.

43 The Tohfa-yi Husām, a vocabulary of Persian words translated into Turkish and commonly misattributed to Husām al-Dīn Khū'ì, was authored by Ḥusām b. Ḥasan al-Qūnavī (fl. c. 1400). Boz, Farsça-Türkçe illk Manzum Sözlük, 69-74.

44 The vocabulary written by Khü' 1 is the Nașib al-fityān, a very popular interlinear translation of the original Arabic work entitled Nișāb al-Șibyān by Abū Nașr Muhammad Badr al-Dīn Farāhī (d. 1243). The date of composition of this work is unknown. Khū' 1 also composed a collection of quatrains entitled multamasāt. On this work, see Hasan'zādah, Darbārah-i àdabī āl chūpān, 47-64; Khū'ī, Majmū'ah, ed. 'Abbās'zādah, 129-153. A manuscript of this work has survived in Tehran, Malek Library 1196/4, fols. 114-157. 
Nuzhat al-kuttāb wa tuhfat al-ahbāab, includes different types of citations from the Qur'ān, the Hadith, advice to Caliphs and Arabic poetry (with Persian translation) that can be used in the writing of letters. ${ }^{45}$ This work, composed in 684/1285 and dedicated to Muzaffar al-Din Chūpān, is considered the best of Husām al-Dīn Khū ${ }^{3} .{ }^{46}$ The second work, the Qawä id al-rasa $\bar{a}^{\prime} i l$ wa farä id al-fad $\bar{a}^{\prime} i l$ is a manual on diplomatic letter-writing composed in Rajab of $684 \mathrm{AH}$ [1285 CE] and apparently dedicated to Amīr Mahmūd b. Muẓaffar al-Dīn Chobanid. ${ }^{47}$

Even if not comparable to the cultural effervescence and sophistication of other Islamic cities of the time, the literary patronage of Muzaffar al-Din was not random. Some of these texts had a clear role as legitimizers of the rule of the Chobanids. On the one hand, the work of Quṭb al-Din Shīrāzi played a role in elevating the prestige of Muzaffar al-Dīn as a respected ruler in the political context of Mongol Anatolia. On the other, the Fusțāt al-'adāla served to portray the Chobanid amir as a rightful Islamic ruler, committed to orthodoxy and diplomatic in bringing together both Shafi'i and Hanafi schools of law. It might be argued that both the Ikhtiyārät-i Muzaffarì and the Fusțāt al-'adāla are ad hoc compositions dedicated to Muzaffar al-Din by individuals with whom no further connection to Kastamonu or its rulers can be attested. However, Husām al-Dīn Khū'ì did live and work in the Chobanid territories and left a corpus of administrative literature that provided a theoretical framework and practical tools for the Turkmen administration of the city of Kastamonu at the crucial moment when the Chobanids were moving into the cities and taking full control over the urban settlements of the region. Inspired by his trip to the Ilkhanid capital, Muzaffar al-Dinn understood that literary patronage could be another important way to consolidate his rule. These authors and their works helped him to legitimize his position beyond the traditional role as a Turkmen military commander. Instead, they offered him the chance to be seen as a ruler interested in the sciences, concerned with religious orthodoxy and preoccupied with the administration of his territories by an urban population that might have questioned both his Islamic credentials and his capacity to rule over the city.

\section{The Role of the >Persianised Eliter}

Following a wider cultural trend that occurred in different local courts of 14th-century Anatolia, Chobanid literary patronage developed a clear preference for Persian as a literary language. ${ }^{48}$ The use of Persian as the main literary language of works dedicated to the court was favoured by the migration of men of letters, scholars and religious personalities with a Persian cultural background from the eastern parts of the Islamic world to Anatolia beginning in the late 12th century. The consolidation of a social class of Persian origin in medieval Anatolia has traditionally been connected with the development of Islam in urban settlements across Asia Minor. ${ }^{49}$ The presence of these individuals sharing a common Persian background (or instructed in Persian literature) has been documented across medieval

45 For an edition of the Nuzhat al-kuttāb, see Khū'ì, Majmü'ah, ed. 'Abbās'zādah, 155-219.

46 Istanbul, Süleymaniye Library, Fatih 5406, fol. 33r.

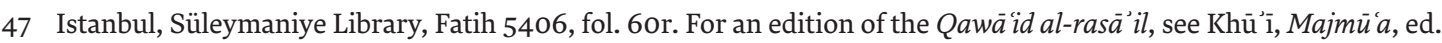
'Abbās'zādah, 222-294.

48 Peacock, Islam, Literature and Society, 175; Riyāhịi, Zabān va ädab.

49 On the presence of individuals of Iranian origin in the early Turkic conquest of Anatolia, see Peacock, Islam, Literature and Society, 33. 
Anatolia. Recent research has suggested that these individuals did not act in isolation but rather formed an interconnected network of literate men sharing similar common cultural backgrounds, religious affiliations and career aspirations..$^{50}$ Their role in the social fabric of urban Anatolia and their relationship with the local Turkmen rulers of Asia Minor is poorly documented and has generated debate among scholars. ${ }^{51}$

However, the relatively rich literary corpus that survives from Chobanid Kastamonu helps us to visualise the role played by some of these individuals in securing patronage in urban settlements. All the men that dedicated works to the Chobanid rulers occupied (or were willing to occupy) positions in the administration of Anatolia. For example, Quṭb al-Dīn Shīrāzì was famously appointed as Qaḍi of both Malatya and Sivas, either by the Mongol official Shams al-Dīn Juwaynī or by the governor of Anatolia Mưin al-Dīn Sulaymān Parwānā (d. 1277). ${ }^{52}$ Similarly, based on the works he wrote, we know that Ḥusām al-Dīn Khü ì would ascend in the Chobanid administration to become a secretary (munshi) at the court in Kastamonu. In the Nuzhat al-kuttāb wa tuhfat al-ahbāb, dedicated to Muẓaffar al-Din, he mentions how he wrote this work for the pleasure of the ruler but also in the hope that, once the book was studied and became useful, he would be given the opportunity to enter into the service of the Chobanid ruler. Speaking of himself, he expressed his wishes in this way: "This poor man [Husām al-Dīn] has risen from the lowest humility (haziziz-i khumūl) to the highest degree of fame (zurwat-i darajat-i shuhrat) by the appointment of His Supreme Highness (hazrat-i ulyāsh) [Muzaffar al-Dīn] to the position of scribe (manșab-i kitābat). «53

Whereas some from this literate class succeeded, others failed, or at least, it is unknown whether they ever reached the position they aspired to. A large part of the of the Fustatt al-'adāla is an adaptation of the famous Siyar al-Mulük, a famous treatise on government produced in the 12th century, with the aforementioned section on heresies added at the end. Nonetheless, the author never mentions his sources, writes the text as if this were his original work, removes the name of the original author and replaces the original dedicatee of the work with the name of Muzaffar al-Din of Kastamonu in the qașida that closes the work. ${ }^{54}$ Surely, the author of the Fustạt al-'adāla was willing to produce a book that suited the taste of his patron, but he also seemed to have a more prosaic objective: the author was especially concerned with proving to his patron his capabilities in writing Persian and Arabic, his deep understanding of Islam and his knowledge of various aspects of court administration. It has been established that the author of the work most probably had a religious background. Therefore, he seems to have anticipated not only a financial reward in presenting this work to the ruler of Kastamonu, but also a position among the religious authorities at the court.

50 De Nicola, Letters from Mongol Anatolia, 77-90.

51 Peacock, Islam, Literature and Society, 46.

52 Walbridge, Science of Mystic Light, 181-183.

53 Istanbul, Süleymaniye Library, Fatih 5406, fol. 33r; Khū' ì, Majmü 'ah, ed. 'Abbās'zādah, 158-159.

54 For the qașida, see Paris, Bibliothèque nationale de France, Turc 1120, fol. 69r-v; Khismatulin, Attribution of an anonymous qasida. 
On occasions, the intentions become rather evident in the text itself: »(...) [The King should] appoint wise and reasonable people to his court (dìvān) and chambers (īwān), so whatever he does, he does it in consultation with wise and elderly people, [those who are] experienced and who know the job." And then, the author adds that the king should command that "all the religious scholars ('ulamá), people of virtue (ahl-i afz̧āl), the pious (dainidār) and devout ( $z a h$ ) should preserve their ranks according to their position. « ${ }^{55}$

The name of Muhammad al- Khațib, possible author of the Fustāt al-'adāla, does not appear in any other source connected to Kastamonu, and consequently, we do not know if he ever accomplished his goal of working for the court. However, we do know that he was not alone in his pursuit of a better professional future. A collection of letters (munsh $a^{\prime} \bar{a} t$ ) written by a certain Sa'd al-Din al-Haqq, a physician who lived in northern Anatolia in the second half of the 13th century, showcase the struggles and complications that these men of letters endured in trying to secure a position in the administration of northern Anatolia. ${ }^{56}$ In some of his writing he complains about the difficulties he had to overcome while working in the region of Zalifre (modern Safranbolu), a city over which control was disputed between the Chobanids and the Byzantine Empire in the 13th century, before beginning a long journey in search of work across different urban settlements of northern Anatolia. In some of these missives, Sa'd al-Dīn al-Ḥaqq describes his travels visiting not only Kastamonu but also Sinop, Tokat, Samsun or Bafra, where he approaches various local Turkmen rulers, trying to secure a role in the administration. ${ }^{57}$ Unlike Khatiib, we know that he secured different positions both as a physician and, thanks to his literary ability, as the Head of Religious Endowments (Daftar-i dìvān-i awqāf)..$^{58}$

As I have shown elsewhere, the case of Sa'd al-Dīn al-Ḥaqq or Muhammad al-Khatīb are not isolated stories, but a common pattern that shows a network of men belonging to a Persianised literary elite who attempted to capitalise on the need that local Turkmen rulers of Anatolia had for their literary skills. ${ }^{59}$ Some of the letters included in Sa'd al-Din's compendium have the name of a certain Husām al-Dīn as the addressee. Recent research has suggested convincingly a possible identification of this person with Ḥusām al-Dīn Khü ì, the prolific author of Chobanid Kastamonu..$^{60}$ The letters addressed to him include commentaries on classical Persian literature, impressions of new literary composition and suggestions about how to improve career prospects in the fragmented administration of Seljuq Anatolia. Unfortunately, only the letters written by Sa'd al-Dīn al-Ḥaqq replying to Ḥusām al-Dīn have survived in this collection and only scattered information about the letters of the latter can be inferred from the responses of the former. However, if the identification is correct, this compendium reinforces the idea of a close network of intellectually active men with a shared Persian cultural background who were actively participating in the administration of different urban settlements in 13th-century Anatolia.

\footnotetext{
55 Paris, Bibliothèque nationale de France, Turc 1120, fol. 118v.

56 De Nicola, Letters from Mongol Anatolia, 80-84.

57 De Nicola, Trip of a medieval physician.

58 Istanbul, Süleymaniye Library, Fatih 5406, fol. 12or.

59 De Nicola, Letters from Mongol Anatolia.

60 Yakupoğlu and Musalı, Selçuklu inşâ sanatı, 73-74.
}

medieval worlds $\bullet$ No. $14 \cdot 2021 \cdot 155-178$ 
Members of this network of literate Muslim men, educated in Persian and Arabic and trained in the art of administration, played a crucial role in facilitating Turkmen control over urban settlements in northern Anatolia. However, we do not know whether these works dedicated to Turkmen rulers ever made it out of the rulers' personal libraries. For example, did Muẓaffar al-Dīn Chūpān or his court ever implement the advice found in the Fusțât al-'adāla or the elaborate Nuzhat al-kuttāb composed for him? Or did these works only serve the authors, as proof of their literary capabilities, in their efforts to achieve positions in the court? The answer may be found not in the most elaborate works of Ḥusām al-Dīn Khū’ì dedicated to the Chobanids, but rather in the »lesser « works he composed while part of the administration of Kastamonu.

\section{Husām al-Dìn Khü ì as an urban agent of medieval Kastamonu}

It is unclear whether the templates prepared by Khù'i in the Nuzhat al-kuttāb or the Qawāid al-rasa $\tilde{a}^{\prime} i l$ were ever used in real diplomatic endeavours or whether they were only a literary exercise produced by the author for the amusement of his patrons. We know that in other parts of the medieval Islamic world, insh $\vec{a}^{\prime}$ literature was often a genre patronised for its elaborate prose and the possibility of elevating the prestige of the ruler rather than for its application to daily administration. ${ }^{61}$ However, the literary legacy of Ḥusām al-Dīn Khü’ ì includes other works that, although dealing with topics similar to those two, offer a different perspective on the relevance which men such as Husām al-Dīn Khü’ì had for the administration of Chobanid Kastamonu. These works are shorter and not dedicated to rulers but rather to members of his family or social class.

The Rusüm al-rasā'il wa nujūm al-faḍäil, for example, was composed in $690 \mathrm{AH}$ (1291 CE) ${ }^{62}$ Only one copy of this work has survived to our day, but in the preface the author mentions that he composed this work for beginners (mubtadiyan) in the job of writing and on request by a group of benevolent and sincere friends (muhibbān-i mun 'am va mukhlașān) to help them in the art of administration. ${ }^{63}$ Another work, entitled Ghunyat al-tālib wa munyat al-kätib, ${ }^{64}$ is very similar in contents to the Qawa'id al-rasä $\bar{a}^{3} l$ but presented as an abridged version, ${ }^{65}$ apparently composed in Rabï II of 709 AH (1309 CE). The author tells us that he dedicated this work to his son Naṣr al-Dīn ibn Ḥusām al-Dīn Khūì but that his father (vālid) inspired the composition. ${ }^{66}$ Hence, unlike those texts dedicated to rulers, these two works seem to have been conceived not to embellish the personal book collection of a ruler but rather as useful literary tools that could serve the daily administration of the kingdom while consolidating the presence of family and friends in different court offices.

61 Paul, Inshā' collections as a source, 535-550; Paul, Some Mongol Inshā’ collections, 277-285; Peacock, Niẓām alDīn al-Iṣfahānī, 13-38.

62 Edition of the Rusūm al-rasä'il in Khū' ì, Majmūa'ah, ed. 'Abbās'zādah, 343-373.

63 Istanbul, Hacı Selim Ağa library, Nurbanu 122, fol. 1 b.

64 Edition of the Ghunyat al-țālib in Khū' ì, Majmūàh, ed. 'Abbās'zādah, 295-342. Both works have also been edited by Adnan Sadık Erzi; see Khū’ì, Gunyetu’l-kätib ve munyetu’ ț-tālib, ed. Erzi.

65 Turan, Türkiye Selçuklulari, 176.

66 Özergin, Selçuklu sanatçisi, 229; Encyclopaedia Iranica, online edition, s.v. "Ḥasan b. 'Abd-al-Mo’men«, accessed on 3 March 2021: www.iranicaonline.org/articles/hasan-b-abd-al-momen. 
In both the Ghunyat al-țâlib and the Rusūm al-rasä'il Ḥusām al-Dīn Khü'ì reproduces a schematic view of the structure that can be used to organise the administration of the realm. However, his design of a hierarchical administration is not new but is based on a traditional Seljuq idea of social order that is readapted for his time and context. ${ }^{67}$ In the Ghunyat alțălib, Khù $\overline{1}$ presents society as divided into different groups (sinf), with each group divided into two different strata (tabaqāt).$^{68}$ The first group consists of the administrative ranks of a realm, with an upper stratum reserved for members of the court and the highest officials, and a lower stratum consisting of administrators generally found in provincial areas. The second group includes members of society that occupy an important role for their religious or literary capabilities - the group in which Husām al-Dīn himself and other members of the literary elite would be located. A final group, including the family connection related to the person in question, closes the diagram of an ideal society.

67 Korobeinikov, Byzantium and the Turks, 84-86.

68 The term șinf (pl. aṣnäf) is often associated with urban artisans and guilds. In this case, however, Khü'i uses the term to refer to a social group or administrative hierarchy in the court. See Encyclopaedia of Islam, Second Edition, s.v. »Ṣinf«, accessed on 3 March 2021: dx.doi.org/10.1163/1573-3912_islam_COM_1085. 


\begin{tabular}{|c|c|c|}
\hline \multirow[t]{2}{*}{$\begin{array}{l}\text { 1. Category } \\
(\sin f)\end{array}$} & $\begin{array}{l}\text { 1. Stratum } \\
\text { (tabaqat) }\end{array}$ & 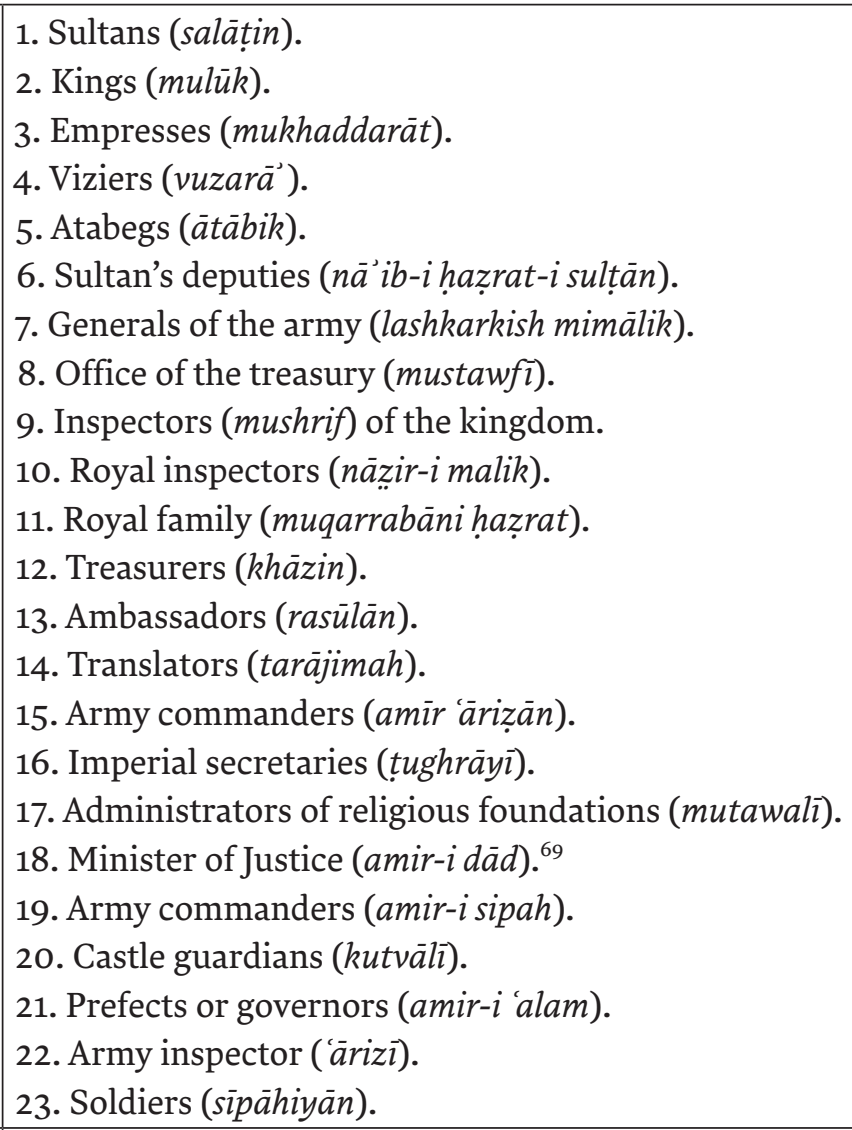 \\
\hline & $\begin{array}{l}\text { 2. Stratum } \\
\text { (tabaqat) }\end{array}$ & $\begin{array}{l}\text { 1. Deputies [of local governors] (näyib). } \\
\text { 2. Princes or provincial governors (vāīi). } \\
\text { 3. Provincial inspectors (mushrif). } \\
\text { 4. Local inspectors (nāzirir). } \\
\text { 5. Tax collectors (qäbiz). } \\
\text { 6. Āmir-i Ikdishān. }{ }^{70} \\
\text { 7. Notables (khwājagān). } \\
\text { 8. Clerks or administrators of the court ('ummāl). } \\
\text { 9. Supervisor of markets and trade (muhtarifah). }\end{array}$ \\
\hline
\end{tabular}

69 Could also be described as Chief Magistrate.

70 The origin of the term is obscure. It appears to be a word brought from Turkish into Persian that, as an adjective, refers to someone of a mixed religious or ethnic origin. As an administrative office, the term appears in Afläkì, Manāqib, 2, ed. Yaziçi, 751, trans. O’Kane, Feats, 652. 


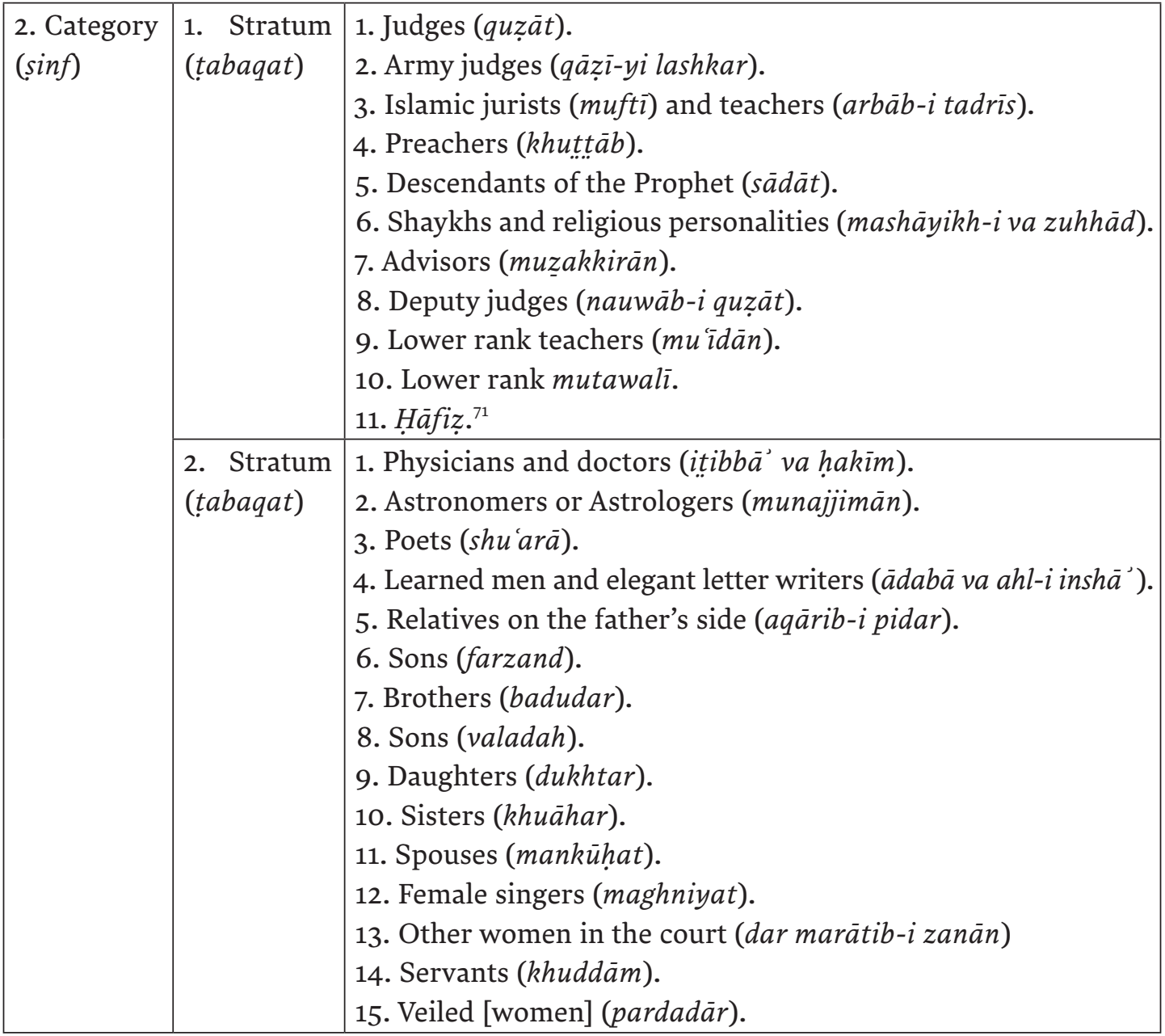

Table 1: Offices listed in the Ghunyat al-țālib wa munyat al-kātib.

In Khü'î's schematic representation of the administration, each office is accompanied by a short formulaic address mixing Persian and Arabic to be used when talking to the person holding that particular office. In other words, Husām al-Dīn Khū'ì provides useful templates for his professional colleagues (secretaries, scribes, officers) and job apprentices, in order to facilitate the development of a coherent protocol for written communication across the administration. Nevertheless, the diagram resulting from the stratification of these posts also reflects a world-view regarding how the court should be organised, a world-view to be transmitted to court officials working for the rulers of Kastamonu. It is not surprising that, in the first group, the author places the higher ranks in the central administration at the top of the hierarchy, with those ranks dealing with regional administration in the second stratum. Presumably, this helps to situate the relationship between the central administration in the first stratum of the group (whether it is the Seljuqs or the Ilkhanate) and the local or provincial official in the second stratum, which could be applied to the region of Kastamonu. The

71 Generally referring to a person who has memorised the Quran, but may also refer to an imam in general. 
second group lists the local administration in terms of justice, religion and economy, but also emphasises the importance of local teachers, men of letters, poets and family members. The two strata in this second group represent, in my view, a proposal for the organisation of the administration at a local level that Husām al-Dīn Khū' ì is promoting in the region. The list of ranks mentioned in the second group would resonate with members of professions often associated with urban centres, who had an important role to play in the Islamic community.

This schematic presentation is largely based on the traditional model of administration developed during the Great Seljuq period. ${ }^{72}$ Although some of these offices might have remained in use in certain parts of the Ilkhanate or at the court of the Rum Seljuqs, with the consequent need for the address formulae to be used, it is unlikely that the model was fully deployed in the more humble administration of Chobanid Kastamonu. Perhaps a more accurate picture of the specific institutions that Husām al-Dīn Khù'ì and his fellow administrators dealt with on a daily basis appears in two sections of the Rusüm al-rasáa $i l$, the other work that he composed for his peers.

In parts three and four of this work, entitled respectively "Court reports on various positions (dar taqrīrāt-i divānī bih munāṣab-i mukhtalif)" and »Reports on legal positions (dar taqrirāt bih manāșib-i shari i) «, a number of administrative posts are listed, one after the other, to serve as a guide for the appointment of individuals to these offices. Instead of formulae for writing letters, however, this list serves to explain the role and responsibilities of a given position in the overall administrative structure. Each report (taqrïrät) includes the word fulän in places where the scribe using the text would include the corresponding name of the person being appointed. The structure of these texts is comprehensive, explaining the reasons for appointment and the merits of the person, as well as emphasising how the new appointee should carry out his new duties by, for example, exerting all his physical and mental effort (ijtihād) on the task. ${ }^{73}$

What is relevant for this essay, however, is that the work presents only a selection of appointments and omits many of the positions listed in the aforementioned schema provided in the Ghunyat al-țälib. Here, in the Rusüm al-rasä'il, only sixteen specific ranks are provided by Husām al-Dīn Khü 1 . The motives behind this selection are not explained in the text; thus, we do not know why these particular positions (and not others) have been included in this section. However, since the text was composed to help his professional colleagues and to provide material for training officials during his time in Kastamonu, the selection may well indicate those posts that actually needed to be filled during the period of Chobanid rule. The offices included in these sections of the Rusüm al-rasä $\overline{i l}^{\prime}$ are as follows: 72 The Great Seljuqs remained an important source of legitimation across Anatolia in the 13th century; see Peacock,
Seljuq legitimacy, 79-95.

73 Khū’ ī, Majmūiah, ed. 'Abbās'zādah, 358. 


\begin{tabular}{|l|l|l|}
\hline N. & Name of the Office & Explanation of the Duties \\
\hline \multicolumn{2}{|l|}{ Appointments included in part 3} \\
\hline 1 & Zi'āmat & $\begin{array}{l}\text { The ruler of a fief granted by the sultan to govern and } \\
\text { extract taxes. }\end{array}$ \\
\hline 2 & Kutwālī & $\begin{array}{l}\text { The person responsible for protecting the common } \\
\text { people within the wall of a castle or citadel (qilā). }\end{array}$ \\
\hline 3 & Niyābat & $\begin{array}{l}\text { The vice-regent or deputy who was able to act in the } \\
\text { name of the Sipahsālār. In Seljuq times, the holder of } \\
\text { this office functioned as a counsellor to the ruler. }\end{array}$ \\
\hline 4 & Iyālat & The governor of a region responding to the Sipahsārr. \\
\hline 5 & Inshā' & A scribe or secretary. \\
\hline 6 & Ashrāf & $\begin{array}{l}\text { A notable member of the council responsible for } \\
\text { determining tax amounts and increasing private income. }\end{array}$ \\
\hline 7 & Nāzirī & An inspector. \\
\hline 8 & Ikdishān & $\begin{array}{l}\text { The head of the city responsible for managing } \\
\text { commercial life. }\end{array}$ \\
\hline 9 & Qābiz̄ī & A tax collector. \\
\hline 10 & Iḥtisāb and 'ummāl & $\begin{array}{l}\text { Agents in charge of collecting taxes from markets } \\
\text { and workers. }\end{array}$ \\
\hline Appointments included in part 4 \\
\hline 11 & Quzāàt & A judge. \\
\hline 12 & Tadrīs-i madrasa & A madrasa instructor. \\
\hline 13 & Khațābat & A religious preacher. \\
\hline 14 & Ṭabībī & A physician. \\
\hline 15 & Shaykh-i khāniqāh & The head of a Sufi hospice. \\
\hline 16 & Tawaliyat & $\begin{array}{l}\text { The administrator or procurator of a religious or } \\
\text { charitable foundation. }\end{array}$ \\
\hline
\end{tabular}

Table 2: Offices listed in the Rusūm al-rasà 'il wa nujūm al-fażà 'il.

The roles of administrative offices and the duties of officials cannot be easily extrapolated from the classical Seljuq period to medieval Anatolia. The terms used to refer to these ranks often referred to different roles in Iran or Anatolia and had different connotations when used in the classical Seljuq administration versus later historical periods. ${ }^{75}$ Unfortunately, Khü' 1 is not precise in describing the exact duties of these offices; his indications of the actual administrative tasks of these institutions are vague, being more interested in stressing, instead, the moral virtues required by the office holder willing to access these offices. However, the selection of offices listed here includes a number of characteristics that allow us to speculate on how these positions would have served the administration of medieval Kastamonu.

74 In Ilkhanid Iran, the $n \bar{a}^{\prime} i b$ acted as deputy to the vizier. Spuler, Mongolen in Iran, 309-310.

75 Korobeinikov, Byzantium and the Turks, 84. 
Different institutions (i.e. niyābat and iyālat) are specifically subordinated to the authority of the Sipāhsālār, the title received by Muzaffar al-Din from the Mongol Ilkhan Arghun after his visit to Tabriz in the early 1280 s. $^{76}$ This suggests that, while many of the offices listed in the Ghunyat al-țalib may be only a theoretical representation of society based on an ideal Seljuq past, those included in this part of the Rusüm al-rasá'il may well be specifically tailored to Chobanid Kastamonu. In the Seljuq context, for example, the zi'amat is understood to refer to the person in charge of controlling a large fief. ${ }^{77}$ However, while the post (in the classical understanding of this office) needed to be assigned by the sultan, the same institution in Khü'î's work is placed under the jurisdiction of the Chobanid ruler. Since the Chobanids were expanding their domains in the late 13th century, specifically adding territories on their western frontier at the expense of Byzantium, this institution could have provided the rulers the privilege of appointing men to be in charge of fiefs in the newly conquered lands. $^{78}$

Additionally, the appointments selected for this section of Khü'i's work are associated with urban settlements. The appointments listed in part three pay special attention to the organisation of government, the regulation of trade and the fiscal administration of the city. While some of these appointments - such as the niyäbat, the iyālat, the insh $\bar{a}$ ' or even the council of notables (ashräf) - seem to be conceived as political roles, others are clearly associated with the collection of revenues for the ruler's treasury (näzirī, qābizì , ihtisāb and 'ummāl). Furthermore, although the aforementioned Byzantine castle remained the main building in the city of Kastamonu throughout the 13th century, it is possible that the responsibility of the kutwäli for the Chobanid capital was not limited to the castle alone, but rather included the entire citadel. In this case, Khü'i might be providing the Chobanid rulers with an institution with which the new Turkmen ruler could establish direct control over the urban population now under his jurisdiction.

The office of the ikdishān also requires some special consideration. It is generally considered an urban institution in charge of collecting taxes on trade and organising the defence of the city against an enemy siege. The meaning of the word seems to carry an inter-racial component, suggesting that the appointee was selected from people of mixed origin. ${ }^{79} \mathrm{Men}$ descending from Turkic fathers and local Christian mothers were especially promoted to this position across medieval Anatolia. They seem to have acquired a high position in different urban settlements in Asia Minor and their mixed origin may have played an important role in facilitating tax collection among the culturally diverse population that inhabited medieval Anatolian cities. ${ }^{80}$

77 TDV İslâm Ansiklopedisi, s.v. "Zeâmet«; Encyclopaedia of Islam, Second Edition, s.v. "Zi'āmet«, accessed on 3 March 2021: dx.doi.org/10.1163/1573-3912_islam_SIM_8163.

78 See, for example, the Chobanid military campaigns against two Byzantine castles in the bay of Gideros, some 150 kilometres northwest of Kastamonu on the coast of the Black Sea. The letter of victory commemorating this event is included in one of Ḥusām al-Dīn's works; see Khū' 1̄, Majmū 'ah, ed. 'Abbās'zādah, 282. Peacock, Seljuk sultanate of Rum, 267-287; Musali and Yakupoğlu, Çobanoğulları Uc Beyliği Dönemine, 77-134.

79 The person holding the office might be of mixed ethnic background (partly Turkmen and partly something else); see Aflākī, Feats, trans. O’Kane, 741.

80 TDV İslâm Ansiklopedisi, s.v. "İ̆ğdiş«. 
While the appointments listed in part three are more concerned with organising political power and economic administration, the fourth part of the Rusüm al-rasá $\bar{a}^{\prime} i$ is centred on religious appointments. As we have seen, religious buildings were not constructed in the city of Kastamonu until the 1270s, but only a few decades after the confirmation of Muzaffar al-Din Chūpān, the city of Kastamonu needed to appoint personnel to take care of religious institutions that had been established in the city. The reference to judges (quzāt), instructors for religious schools (tadris-i madrasa), preachers for the mosques (khatābat) or individuals responsible for Sufi hospices (shaykh-i khāniqāh) and religious foundations (tawalìt) suggests that at the turn of the 14th century, when this work was composed, a consolidation of Islamic institutions was well underway in medieval Kastamonu. Because they were not conceived as literary masterpieces for the satisfaction of a patron, but rather as practical manuals for the administration of the realm, both the Ghunyat al-țalib and the Rusüm al-rasä il bear testimony to the simultaneous processes of Islamisation and Turkmen appropriation of urban centres that occurred in northwestern Anatolia under the Chobanids. They offer a social and administrative model based on an idealised Seljuq past, as well as providing pragmatic documentary evidence of the effort to consolidate the Chobanid administration in an urban settlement such as Kastamonu, which, by the end of the 13th century, was being claimed by the Turkmen rulers who had once acted solely as military protectors of the urban population. Ḥusām al-Dīn Khū' 1 and other members of this administrative elite rooted in a Perso-Islamic tradition were crucial in facilitating these processes.

\section{Conclusion}

The lack of references to the region of Kastamonu in the main narrative sources of the period has left northwestern Anatolia out of the larger historical debates about the relationship between Turkmen rulers and urban settlements. However, we hope that by giving an overview of some of the archaeological and literary evidence surviving from the period, we have shed some light on how this interaction evolved throughout the 13th century. The proliferation of shrines and the foundation of modest rural mosques in the area during the first half of the 13th century shows that the Turkmen population initially remained outside the city, inhabiting the countryside outside Kastamonu and controlling the trade routes that connected the Black Sea with Central Anatolia and Byzantium. Because no Christian buildings survive inside the city of Kastamonu for this earlier period, with the exception of the renovated Byzantine castle, it would be misleading to make a clear distinction between a Turco-Muslim rural population and a Christian urban population before the 1270s. However, if Muslim populations lived inside the citadel prior to that date, they left no monumental evidence that has been discovered so far. Instead, the Muslim (and especially Turkmen) presence seems clear after this time, when the presence of Chobanid rulers in the urban landscape of Kastamonu and other cities of the region becomes apparent.

Beginning in the early 1280s, and coinciding with the ascension of Muzaffar al-Din Chūpān to the throne, the religious transformation of Kastamonu into a Muslim territory documented in the archaeological evidence is mirrored in the textual evidence. Literary patronage becomes a way to authenticate the political recognition obtained from the larger regional powers in Konya and Tabriz, legitimising Turkmen rule in the eyes of the local urban population. In addition, the active role of these rulers in financing the production of literary works in Persian visualises the presence of an administrative elite that appears to play a crucial role in providing the knowledge, the manpower and the theoretical tools to facilitate the establishment of Turkmen rule in cities such as Kastamonu. 
Overall, both architectural and literary sources provide evidence of the presence of Turkmen rulers and a Persianised literary and religious elite acting as agents in facilitating Chobanid rule in 13th-century Kastamonu. It is impossible, with the available sources, to ascertain whether the urban Christian populations saw the proliferation of Islamic buildings as an imposition or whether the appearance of these buildings was the unavoidable culmination of a process of Islamisation which the Chobanids only accompanied as rulers. However, whereas details on the interaction between Christian populations and the Chobanid rulers is missing from the available sources, the policies of literary patronage initiated by Muzaffar al-Dīn reveal the different agencies actively participating in Chobanid Kastamonu. The architectural legacy and the production of a rich literary corpus of scientific, religious and administrative literature stand as evidence of a collective agency that consciously or unconsciously shaped the landscape and social fabric of the city of Kastamonu and its surroundings during the 13 th century.

\section{Acknowledgements}

This work was supported by the Austrian Science Fund under Grant FWF-START, Nomads' Manuscripts Landscape, Y-1232 G30; European Research Council under Grant ERC-StG. The Islamisation of Anatolia, c. 1100-1500, n. 208476. 


\section{References}

\section{Manuscripts}

Istanbul, Hacı Selim Ağa library, Nurbanu 122.

Istanbul, Süleymaniye Library, Fatih 5406.

Istanbul, Süleymaniye Library, Fatih 5302.

Paris, Bibliothèque nationale de France, Turc 1120.

Tehran, Malek Library 1196/4, fols. 114-157.

Acar, Hüsnü, Çobanoğulları Beyliği Dönemi ve Kastamonu Fatihi Emir Hüsameddin Çoban Bey (Istanbul, 1997).

Aflākī, Shams al-Dīn Aḥmad, Manāqib al-'ärifìn. ed. Tahsin Yaziçi, 2 vols. (Ankara, 19591961). English translation: John O'Kane, The Feats of the Knowers of God: Manaqeb al-'Arefin (Leiden, 2002).

Akropolites, Georges, George Akropolites: The History, trans. Ruth Juliana Macrides (Oxford, 2007).

Anonymous, Tārìkh-i Āl-i Saljūq dar Ānāț̣ūlì, ed. Nādirah Jalālī (Tehran, 1999).

Aqsarā '̄i, Karīm al-Dīn Maḥmūd ibn Muhammad, Musāmarat al-akhbār va musāyarat al-akhyār, ed. Osman Turan (Ankara, 1944).

Boz, Erdoğan, Farsça-Türkçe ilk Manzum Sözlük Tuhfe-i Hüsami’nin Bursa (ineybey) Nüshası, in: Osmanlı Bursası'nda Dil-Kültür ve Edebiyat Bilgi Şöleni, 29-30 Mayıs 2013, (Bursa, 2013) 69-74.

Cahen, Claude. Pre-Ottoman Turkey: A General Survey of the Material and Spiritual Culture and History, c. 1071-1330 (New York, 1968).

Çal, Halit and Özlem Ataoğuz Çal, Kastamonu Atabey Gazi Camisi ve Türbesi Hazirelerindeki Mezar Taşları (Kastamonu, 2010).

Çelebi, Kâtib, Keşf-el-Zunun, ed. Şerefettin Yaltkaya and Kilisli Rifat Bilge (Istanbul, 1972).

Choniates, Niketas, O City of Byzantium: Annals of Niketas Choniatès, trans. Harry J. Magoulias (Detroit, MI, 1984).

Çiftçi, Fazıl, Kastamonu Camileri-Türbeleri ve Diğer Eserler (Ankara, 1995).

Ciociltan, Virgil, The Mongols and the Black Sea Trade in the Thirteenth and Fourteenth Centuries (Leiden, 2012).

De Nicola, Bruno, The Fusțāt al-'adāla: a unique manuscript on the religious landscape of medieval Anatolia, in: A. C. S. Peacock and Sara Nur Ylldız (eds.), Literature and Intellectual Life in Islamic Anatolia in the 14th-15th Centuries: Historical, Social and Political Perspectives (Würzburg, 2016) 49-72.

De Nicola, Bruno, Letters from Mongol Anatolia: Professional, political and intellectual connections among members of a Persianised elite, Iran: Journal of the British Institute of Persian Studies 56 (2018) 77-90.

De Nicola, Bruno, In the outskirts of the Ilkhanate, in: Suzan Yalman (ed.), Cultural Encounters in Anatolia in the Medieval Period: The Ilkhanids in Anatolia (Ankara, 2019) 117-135.

De Nicola, Bruno, The trip of a medieval physician: a rare description of mobility in Mongol Anatolia, in: Claudia Rapp and Yannis Stouraitis (eds.), Microstructures and Mobility in Byzantium (Vienna, forthcoming).

De Nicola, Bruno, The Chobanids of Kastamonu: politics, patronage and religion in 13thcentury Anatolia (London, forthcoming). 
Döğüş, Selahattin, Osmanli Fütuhatina Candarli Sahasindan Gelen Yardimlar Faaliyetleri, in: Halil Çetin (ed.), Kuzey Anadolu'da Beylikler Dönemi Sempozyumu (Çankırı, 2012) 415416.

Encyclopaedia of Islam, Second Edition, ed. Peri Bearman, Thierry Bianquis, C. Edmund Bosworth, Emeri J. van Donzel, and Wolfhart Heinrichs (Leiden, 1960-2005). Accessed on 3 March 2021: referenceworks.brillonline.com/browse/encyclopaedia-of-islam-2.

Encyclopaedia Iranica, vol. 1-16 (London, 1982-2020); online edition (New York, 1996-). Accessed on 3 March 2021: iranicaonline.org.

Gregoras, Nicephoros, Byzantina Historia, ed. Ludwig Schopen, 3 vols. (Bonn, 1829-1835).

Ḥasan'zādah, Shahriyār, Darbārah-i ādabī āl chūpān (saljūqī) va Ḥusām al-Dīn Khūyī, mubd'-i Multamisāt-i shi'rī, Faṣl'nāmah-i 'ilmī Pizhūhish'hāiyi ādabiyāt-i fārsī, 9/22 (1392 SH) 47-64.

Ibn Bațututa, The Travels of Ibn Battuta, A.D. 1325-1354, ed. and trans. H. A. R. Gibb, C. Defrémery and B. R. Sanguinetti, 2 (Cambridge, 1962).

Ibn Bībī, El-Evamirü'l-'Alâ'iyye fi'l-Umûri'l- 'Alâ'iyye, ed. Adnan Sadık Erzi (Ankara, 1956).

Ibn Bībī, al-Avāmir al-'alà'iyah fì al-umūr al-'alā'ìyah, ma'rūf bih, Tärīkh-i Ibn Bībì, ed. Zhālah Muttahidīn (Tehran, 2011).

Kara, İlyas, Her yönüyle tarihten günümüze Kastamonu, 1 (Kastamonu, 1997).

Khū'ì, Ḥusām al-Dīn, Gunyetu'l-kātib ve munyetu'ț-țâlib: Rusūmu'r-Resā'il ve nucūmu'l-Fazāìil, ed. Adnan Sadık Erzi (Ankara, 1963).

Khū'ì, Ḥusām al-Dīn, Majmū 'ah-'i așār-i Hịsām al-Dìn Khūyì, ed. Șughrá 'Abbās'zādah (Tehran, 2000).

Khismatulin, Alexey, Attribution of an anonymous qasida appended to the first redaction of the Siyar al-mulūk: Stylometry Results. Melanie Gibson and Ali M. Ansari (eds.), Fruit of Knowledge, Wheel of Learning: Essays in Honour of Prof. Carole Hillenbrand 1 (London, 2022) 106-119.

Korobeinikov, Dimitri, Byzantium and the Turks in the Thirteenth Century (Oxford, 2014).

Korobeinikov, Dimitri, The Revolt of Kastamonu, c. 1291-1293, Byzantinische Forschungen 28 (2004) 87-118.

Kuru, Çakmakoğlu, Çankırı Fatihi Emir Karatekin'in Türbesi, Bilig 43 (2007) 63-84.

Musali, Namiq and Cevdet Yakupoğlu, Çobanoğulları Uc Beyliği Dönemine Ait Gideros Fetihnâmesi (683 / 1284): Çeviri ve değerlendirme, Tarih Araştırmaları Dergisi 37/63 (2018) 77-134.

Neville, Leonora Alice, Guide to Byzantine Historical Writing (Cambridge, 2018).

Niazi, Kaveh, Quțb al-Din Shiraizi and the Configuration of the Heavens: A Comparison of Texts and Models (New York, 2014).

Özergin, Kemal, Selçuklu sanatçisi nakkas Abdülmü’min el-Hoyî hakkinda, Belleten 34/134 (1970) 219-229.

Pachymeres, George, Relations historiques, ed. and trans. Albert Failler (Paris, 1984).

Paul, Jürgen, Inshā' collections as a source on Iranian history, in: Bert Fragner, Christa Fragner, Roxane Haag-Higuchi, Mauro Maggi and Paola Orsatti (eds.), Proceedings of the Second Conference of Iranian Studies (Rome, 1995) 535-550.

Paul, Jürgen, Some Mongol Inshä’ collections: The Juvayni Letters, in: Charles Melville (ed.), Proceedings of the Third European Conference of Iranian Studies, 2 (Wiesbaden, 1999) 277-285. 
Peacock, A. C. S., The Saljūq campaign against the Crimea and the expansionist policy of the early reign of 'Alā' al-Dīn Kayqubād, Journal of the Royal Asiatic Society 16/2 (2006) 133-149.

Peacock, A. C. S., Black Sea trade and the Islamic world down to the Mongol period, in: Gülden Erkut and Stephen Mitchell (eds.), The Black Sea: past, present and future: proceedings of the international, interdisciplinary conference, Istanbul (London, 2007) 65-72.

Peacock, A. C. S., Seljuq legitimacy in Islamic history, in: Christian Lange and Songül Mecit (eds.), The Seljuqs: Politics, Society and Culture (Edinburgh, 2011) 79-95.

Peacock, A. C. S., The Seljuk sultanate of Rum and the Turkmen of the Byzantine frontier, 1206-1279, al-Masaq 27 (2014) 267-287.

Peacock, A. C. S., Islam, Literature and Society in Mongol Anatolia (Cambridge, 2020).

Peacock, A. C. S., Niẓām al-Dīn al-Ișfahānī, "Chief Qadi of China and the East «: an Ilkhanid man of letters at the court of the Juwaynis, in: Timothy May, Bayarsaikhan Dashdondog and Christopher P. Atwood (eds.), New Approaches to Ilkhanid History (Leiden, 2020) 13-38.

Pfeiffer, Judith, Politics, Patronage and the Transmission of Knowledge in 13th-15th Century Tabriz (Leiden, 2013).

Riyāhịi, Muḥammad Amīn, Zabān va ādab-i Färsì dar qalamraw-i 'Ușmānī (Tehran, 1990).

Sevim, Ali and Yasar Yücel, Türkiye Tarihi. 1, Fetihten Osmanlilara Kadar 1018-130o (Ankara, 1995).

Spuler, Bertold, Die Mongolen in Iran: Politik, Verwaltung und Kultur der Ilchanzeit 12201350 (Berlin, 1955).

Turan, Osman, Türkiye Selçuklulari hakkında resmî vesikalar: metin, tercüme ve araştırmalar (Ankara, 1958).

Türkiye Diyanet Vakfi İslâm Ansiklopedisi (Istanbul, 1988-2013).

Vryonis, Speros, The Decline of Medieval Hellenism in Asia Minor and the Process of Islamization from the Eleventh through the Fifteenth Century (Berkeley, CA, 1971).

Walbridge, John, The Science of Mystic Light: Quṭb al-Dìn Shiräzi and the Illuminationist Tradition in Islamic Philosophy (Cambridge, 1992).

Yakupoğlu, Cevdet, Kastamonu-Taşköprü Çobanoğlu Muzaffereddin Yavlak Arslan Medresesi ve Camii, Tarih Araştırmaları Dergisi 36/61 (2017) 41-74.

Yakupoğlu, Cedvet and Namiq Musalı, Selçuklu inşâ sanatı: Hasan b. Abdülmü'min el-Hôyî̀nin kaleminden (Ankara, 2018).

Yaman, Talât Mümtaz, Kastamonu tarihi (Kastamonu?, 1935).

Ylldız, Sara Nur, Mongol Rule in Thirteenth-century Seljuk Anatolia: The Politics of Conquest and History-Writing, 1243-1282. Unpublished PhD thesis (University of Chicago, 2006).

Yınanç, Halil, Anadolu Selçukiler tarihine ait bazı kaynaklar, in: III. Türk Tarih Kongresi (Ankara, 1948) 95-103.

Yücel, Yaşar, Anadolu Beylikleri Hakkında Araştırmalar, 2 vols. (Ankara, 1991).

\section{List of tables}

Table 1: Offices listed in the Ghunyat al-țälib wa munyat al-kātib.

Table 2: Offices listed in the Rusūm al-rasä'il wa nujūm al-fażä'il. 